\title{
Improving Students' Speaking Skill through Communicative Activities In Small Group Discussions at the Third Semester Class A Of the English Study Program of FKIP UNRI.
}

\author{
Hadriana \\ University of Riau
}

\begin{abstract}
This research was intended to know whether communicative activities in small group discussions can improve the students' speaking skill at the third semester Class A of the English Study Program of FKIP UNRI. The researcher was helped by a collaborator and used observation sheets and field notes as the instruments of the research. Besides, she also used speaking test to see the improvement of students' speaking skill on each cycle. The research started on September 23, 2008 and ended on January 9 , 2009.
\end{abstract}

At the beginning of cycle 1 the average score of the students' speaking skill was 48.3. At the end of cycle 1, it improved to 55.7, at the end of cycle 2 it improved to 62.6, and at the end of cycle 3 it improved to 73.4. The factors of communicative activities in small group discussions that influence the students' speaking skill are: (1) Clear objectives; (2) problem solving activities; (3) a good classroom atmosphere; (4) natural learning process (5) uncontrolled materials; (6) indirect corrections; and (7) interaction with partners or group members.

Based on the finding, it was concluded that communicative activities of small group discussions can improve students' speaking skill at the third semester Class A of the English Study Program of FKIP UNRI

Keywords: speaking skill, communicative activities, small group discussions 


\section{A. Introduction}

Based on the curriculum of English Study Program of.FKIP UNRI, S1 students are given 3 levels of speaking classes, namely: Speaking I, Speaking II, and Speaking III. Before taking Speaking-I class which is given at the second semester, at the first semester the students were given a program-which is called Intensive Course. Intensive Course is a program of studying in which the students are involved in activities of Listening, Speaking, Reading, Writing, Listening, Structure, Vocabulary and Pronunciation in an integrated way intensively. The general purpose of this program is to improve the students' skill in communication at intermediate level so they can join the lessons on Semester II without too many difficulties. Furthermore, the students are intended to be able to continue studying Speaking, Listening, Reading, Writing and other subjects in more confident ways. In fact, although the students had completed Intensive Course program, some students and lecturers claimed that they could not speak English effectively yet.

Last semester, specifically from February until June 2008, the researcher had a responsibility to teach Speaking $I$. At that time, the number of students joining that class was 27 . In order to know the level of their speaking skill at the beginning of semester the researcher gave them a pre-test, by asking them to deliver 2-3 minutes oral presentation. After analyzing the students' speaking performance based on criteria adapted from Brown, the average score of their speaking test was only 45.65. Next, after two months of studying the students were given a mid test: Still, the result of the test was not yet satisfactory because the average score of their speaking test was only 62.4. More than half of the students still had problems with their speaking. The problems were related to-all . components of speaking: pronunciation, structure, vocabulary, fluency, and content. The problems were still continuing till the end of semester. Moreover, the researcher thought that the improvement of the students' speaking skill during the whole semesters was quiet slow. The researcher presumed that there were several problems faced by the students.

Their problems caused by several factors: (a) the factors that came from the students; (b) the social atmosphere in the classroom; and (c) the factors that came from the lecturer.

The factors that came from-the students for examples: feeling afraid of making grammatical errors in their speech, uncomfortable feeling in pronouncing 
the words or sentences, and lack of vocabulary. Moreover, when speaking, the students had to give response automatically at the appropriate time. As a result, the students preferred not to speak and became passive learners

The next factor was related to social atmosphere during teaching and learning process in the classroom. A good class atmosphere, would make the students feel free to ask questions and express their ideas without being overly worried about making mistakes. Good sense of humor from the lecturer would also help, because reasonable amount of humor and laugh in class generally had a positive relaxing effect on the students.

The factor that came from the lecturer concerned with her teaching techniques. The speaking activities in the classroom usually consisted of students' repeated after the teacher, memorized new vocabulary and phrases, then involved the students in giving a short speech or retelling a story. The lecturer also focused on correcting the students' grammar as well. These techniques of teaching belong to teacher-centered classroom. The result was that the students were able to say and write the sentences accurately in class but would face difficulties in using their English in real situation or in oral communication outside the classroom.

To solve the problem, the teacher should improve her teaching technique from teacher-centered to learner-centered. In fact, the lecturer has been trying to apply learner-centered class but not yet well-organized. The primary goal of learner-centered class was to promote the students' involvement and interaction. The lecturer should not take up class time by lecturing the materials only, but as much is possible, spent the time to students' activities (Matthews, 1994:7). In line with Matthews, Applebaum in his article Communicative Language Teaching: Theory, Practice and Experience mentions that in learner-centered class, the students are provided with more opportunities in using their English in an authentic and realistic way. The teacher may create many opportunities for students to produce sentences and learn the language in activities and let them learn from the experience, and take more ownership of their own leaming. Retrieved on September 10,2008, (http://www.kopertis2.org/jumal/humaniora.pdf).

From the explanation above, it can be inferred that the teacher can improve the students' speaking skill by giving the students enough practice, because practice gives the students opportunities to use and master the language. Effective practice can be done by conducting communicative activities. At the same time, 
communicative activities may improve the students' motivation to communicate because the students are involved in activities that give them both the desire to communicate and a purpose which involves them in the use of language. Such activities are important to a language classroom since the students can do their best to use the language as individuals, arriving at a degree of language autonomy. The problem then, the lecturers should know how to apply the communicative activities in the classroom.

Harmer (1991:122); Littlewood (1991:20); Ur (1996:121); and Thombury. (2006:79-82) mention that communicative activity can be applied through the activity which is called small group discussions, because small group discussions fulfills two important language learning needs: prepare students with real-life language use, and encourage the atomization of language knowledge. Moreover, small group discussions is an effective way that can be used in teaching speaking since it will increase the amount time for students' talk during the given period of time. Moreover, it also lowers the inhibitions of the students who are unwilling to speak in front of the whole classes.

Based on the explanation above, the purposes of the research are: (1) To explain whether communicative activities in small group discussions can improve students' speaking skill at the third semester class A of the English Study Program of FKIP UNRI; (2) To find out factors of communicative activities in small group discussions that influence the students' speaking skill at the third semester class A of the English Study Program of FKIP UNRI. Hopefully; the result of this research will give contribution to: (1) The lecturers of the English Study Program of FKIP UNRI who are interested in applying communicative activities of small group discussions to improve the students' speaking skill; (2) The researcher herself who has experience in conducting communicative activities in small group discussions in teaching speaking; (3) Students of the English Study Program of FKIP UNRI about the level of participation they should perform during their speaking classes; (4) Everybody who reads this research to have an insight about the use of communicative activities in small group discussions in teaching speaking; (5) Other educators or researchers who want to get the input and stimulate for executer of relevant research in the future. 


\section{B. Review of Related Literature}

\section{Speaking Skill .}

Learning English, especially speaking is considered difficult for many students. Homby (1987:827) states that speaking is the ability of people to make use the language in ordinary one. Then $\operatorname{Ur}(1996: 120)$ says that of all the four skills, speaking seems intuitively the most important so that people who know a language are referred to as "speakers" of that language. Burn and Joyce (1997: 32) state that speaking is an interactive process of constructing meaning that involves producing, receiving and processing information. On the other side, Nunan (1998:39) says that mastering the art of speaking is-the single most important aspect of learning second or foreign language, and success is measured in terms of the ability to carry out a conversation in the language. Moreover, learning to speak requires more than knowing its grammatical and semantic rules. Learners are also required to have the knowledge of how native speakers use the language in the context of structured interpersonal exchange. In other words, the learner must be able to speak the target language fluently and appropriately.

Ur (1996:120) suggests his idea about characteristics of successful speaking activity: (1) Learners talk a lot. As much as possible the teachers should allocate more time and opportunities for students to talk; (2) Participation is even. This means that classroom discussions are not dominated by a minority of talkative students, but every students has a chance to speak; (3) Motivation is high. Students are eager to speak because they are interested in the topic and have sometuing new to talk about; (4) Language is of an acceptable level. Students are able to express themselves in utterances that are relevant, easily comprehensible to each other, and of an acceptable level of language accuracy.

Anyway, to gain the above characteristics is not easy. There are some problems faced by the teachers in getting the students to speak. In the students' point of view, there are some problems why it is difficult for them to speak. Ur (1996:121) states the following factor: (1) Inhibition. Students are often worried about making mistakes, fearful of criticism or loosing face, or simply shy of attention their speech attracts; (2) Nothing to say. It is often heard they complain that they cannot think of anything to say; (3) Low or uneven participation. Only one student can talk in one time if he/she wants to be heard; and in a large class this means each student will have only a very little time taking; (4) Mother-tongue 
use. In classes where lots of students share the same mother tongue; they may tend to use it, because it is easier.

The teachers, however, may not be confused or disappointed with' these situations. They should use their experiences and authorities to solve the problems. The following things can be held by the teachers, Ur (1996:121): (1) Use group work; (2) Base the activity on easy language; (3) Make a careful choice of topic and task to stimulate interest; (4) Keep students speaking the target language.

How can the teachers assess the students' skill in speaking? The followings are some kinds of components and rubrics of speaking test from some experts. In order to know the level of students' speaking skill, of course, the students have to demonstrate or perform their performance of speaking based on criteria of speaking test or rubric for oral communications. Harris (1969:108) considers five components which should be included in testing the students speaking skill. They are: pronunciation, structure, vocabulary, fluency, and understanding or content.

Weir (1993:104) has ahother opinion. He states that there are five components of scoring in speaking test. They are: accuracy, appropriateness, adequacy of vocabulary, grammatical accuracy, intelligibility, fluency, and relevance of content. Each of the components has four levels of ratings that will state the level of the students' speaking skill from low to high.

Another opinion is given by O'Malley (1996:68). He explains that there are three components of scoring in speaking test. They are: fluency, structure and vocabulary. Each scoring has six levels of rating that shows the students' level of speaking skills. Furthermore, Brown and Yule (1999:104) explains that the teacher should prepare a certain form when evaluate students' speaking performance. The form includes:-type of speech required, grammatical correctness, appropriate vocabulary, fluency or pronunciation, and information transfer. While Brown (2004:265) explains that a communicative test has to meet some criteria: it has to test for grammatical, discourse, sociolinguistic, and illocutionary competence as well as strategic competence

Since there are many opinions about methods on how to assess the students' speaking skill, it is necessary for the researcher to choose the components that will be used to assess the students' speaking skill. In this research, the components that are chosen to be assessed are: pronunciation, grammar, vocabulary, fluency and 
content. The reason is simple. These components are used by many linguists mention above: While the scoring rubric will be adjusted to the situation, condition and the level of students' background knowledge. The scoring of each components help the teacher explain the level of students' speaking skill easily and objectively. Based on the explanation above, the indicators of students' speaking skills used in this research are: (1) pronunciation; (2) grammar; (3) vocabulary; (4) fluency; and (5) content.

\section{Communicative Activities}

Language contains many "systems", one of which is the system of grammar. Mastery of grammar is still important in-order to be successful in communication. But since the early 1970's there is a movement in foreign language teaching. The movement is called "communicative movement" (Littlewood, 1991: x). Since that time the goal of foreign language learning is communicative ability: It makes the teacher consider that language not only in terms of its structure (grammar and vocabulary), but also in terms of communicative functions that it performs. In other words, the teacher should begin to look not only at language forms, but also at what the students do with these forms when they want to communicate with each other. Moreover, the teacher should strongly aware that it is not enough to teach the students the structure of the foreign language only. The teacher must also teach the students how to relate this structure to their communicative functions in real situations and real time. The teacher, therefore, should provide the students with opportunities to use the language themselves for communicative purposes.

In order to be able to use the language in communication, the students need a lot of practice. Ur (1996:21-22) mentions about the function of practice in learning language skill. He says that, Practice is the activity through which language skills and knowledge are consolidated and thoroughly mastered. There are three stages or process of learning a skill: verbalization, automatization, and autonomy. In the process of verbalization, the teacher may explain the meaning of the words or the zules about grammatical structures as well as_using them in context. The verbalization may be elicited from learners rather than done by the teacher. The teacher then gets the leamers to demonstrate the target behavior, while monitoring their performance. At first the students may do things wrong and need correcting. Later, they may do it right as long as they are thinking about it. At this point they start practicing: performing the skillful behavior again and again, usually in the 
exercises suggested by the teacher, until they can get it right without thinking about it. At this point they may be said to have "automatized" the behavior.

Later, the students take the set of behaviors they have mastered and begin to improve their own, through farther practice activity. They start to speed up performance, to perceive or create new combinations, to "do their own thing": they are now "autonomous". Some people call this stage "production". In short, the process can be summarized as follows, $\operatorname{Ur}$ (1996:22).

\section{SKILL LEARNING}

\section{VERBALIZATION}

Teacher describes and demonstrates the skilled behavior to be learned; leamers perceive and understand.

\section{AUTOMATIZATION}

Teacher suggests

exercises; learners

practice skill in

order to acquire

facility, automatize;

teacher monitors.
AUTONOMY

Learners continue to use skill on their own, becoming more proficient and creative.

Much practice must be done during the language skill development, because it is essential for successful language learning. Thombury (2006:80) says that practice makes-if not perfect-at least, fluent. For that, the teacher should be able to create opportunities that let the students practice to use the language in a meaningful way and leam from experience. One of the techniques is by applying communicative language teaching and creating communicative activities. Through communicative activities the teacher can create leamer-centered classroom that makes the students more active and productive and their motivation will improve as well. Moreover, Communicative activities may help automization (Thombury, 2006:80).

Littlewood (1991:16-18) has an opinion about communicative activities. He mentions that communicative activities can: (a) provide 'whole-task practice'; (b) improve motivation; (c)-allow natural leaming; (d) create context which support learning. Moreover, communicative activity provides the students with the necessary linguistic forms and the necessary links between forms and meanings 
The teacher then, should design the activity that provide opportunity for the students to produce language that they had recently learned.

Another opinion about communicative activities is given-by Harmer (1991:50). He mentions some differentiation between non-communicative activities and communicative activities as the following figure.

NON-COMMUNICATIVE ACTIVITIES

- no communicative desire
- no communicative purpose
- form not content
-one language item
- teacher intervention
- materials control

COMMUNICATIVE ACTIVITIES

The six characteristics of communicative activities form a continuum of classroom activity in teaching speaking. For non-communicative activities there will be no desire to communicate on the part of students and they will have no communicative purpose. In other words, the students are involved in a drill or repetition, they will be motivated not by a desire to reach a communicative objective, but they need to reach the objective of accuracy. The emphasis is on the form of the language, not its content. Often only one language item will be the focus of the attention and-the teacher will often intervene to correct mistakes, nominate students, and generally ensure accuracy. And of course the materials will be designed to focus on a restricted amount of knowledge. The students, however, have to deal with a variety of language. This will undermine the communicative purpose of the activity.

Based on the theories about the characteristics and principle of communicative activities mentioned above, the researcher states the indicators of communicative activity used in this research. They are: (1)The activity may improve the students' motivation; (2) The activity provides the "whole-task" practice; (3) The activity allows natural leaming (authentic and meaningful); (4) The activity has a communicative purpose; (5) The activity makes the students 
have a desire to speak; (6) The activity focises on language use rather than usage; (7) The activity provides no restriction on the language use; (8) The activity requires the students to interact each other; (9) The activity has a clear outcome, especially the one that requires the students to work together to achieve a purpose; (10) The activity should be without teacher intervention or direct correction.

\section{Small Group Discussion}

Small group discussion or working in a small group is arrangement of students into small groups to participate in a range of activities to develop thinking or to complete practical task. It has been shown to improve the students' understanding and retention of material. Dobson (1981:60), Harmer (1991:123), and Thombury (2006:102) say that discussion is an excellent way to give students opportunities to speak, especially if the class is a large one. Moreover, it is widely practicedat all levels of teaching as well. Part of the problem here is concern with the ways the teacher conducts the discussion.

Sometimes, a discussion may develop spontaneously during the lesson period. Such discussion is a successful discussion, but it cannot be planned. In order to be successful, small group discussion must be'carefully structured and the students must receive support as well. There are some techniques that can be used to make the students talking. They are: (1) put the students into group first; (2) give the students a chance to prepare; (3) give the students a task Harmer (1991:124).

Harris (2007) offers some useful hints to make group discussion work well (http:www.vcu.edu/cte/resources/nfg/14-04-minimizing-perils-of.htm) retrieved on November 12, 2008. They are as follows: (1) Group size: ideal group size is from 4-6; (2) Teaching philosophy: make sure that the students understand why the teacher uses group discussion; (3) Group member selection; (4) Icebreakers: Make sure the students know each other before they begin a group activity, (5) Scaffolding the group work; (6) Self and peer evaluation: Consider having student write a confidential mid-term and final self and peer evaluation; (7) Assigning roles; (8) Reflection on group work.

Through a well-planned process as suggested above, a small group discussion offer the opportunity for the students to be more active participants, making them partners in educational process. 
Finally, based on the explanation above it can be concluded that small group discussions will create a safe and active learning environment for the students to participate freely in the educational process. At the same time small group discussions also improve the knowledge of sharing and interaction among the students and the teacher as well. So the indicators of small group discussions are as the following: (1) Carefully structured; (2) Formulate clear expectations and instructions or directions; (3) Help students learn to think; (4) Provide benefits: independent thinking and problem solving; (5) Provide interaction; (6) Encourage participation; (7) Provide positive feedback; (8) Provide non-verbal communication

\section{Research Methodology}

This research was a classroom action research. The researcher chose this kind of research because she wanted to improve her quality of teaching This opinion is in line with what Kemmis and Mc Taggart (1988), and Mills (2003:5) state that action research is a systematic inquiry conducted by the teachers or researchers to gather information about how well their particular school operates, how well they teach and how well their students learn. At the same time, the purpose of action research is to improve the quality of teaching and learning process.

The research was done at the English Study Program of FKIP UNRI. Participants of this research were the third semester students at class A who were taking Speaking II, academic year 2008-2009. The number of the students was 36.

To get the data, the-researcher used the instrumentation as follows: (1) an oral presentation tests, used to evaluate the students' performance; (2) The obsenvation sheet for the lecturer's and the students' activities; (3) field notes, a kind of notebook for recording the thoughts and events during the teaching and learning process that were not covered on the observation checklists. Then all of the data were analyzed in quantitative and qualitative form.

One example of the teaching procedures is that, the researcher divided the students into small groups, group of two and group of four. To guide the students came into the materials and to stimulate their interest in the topic, the researcher asked the students to view a picture for a few seconds. This is one example of the picture: 


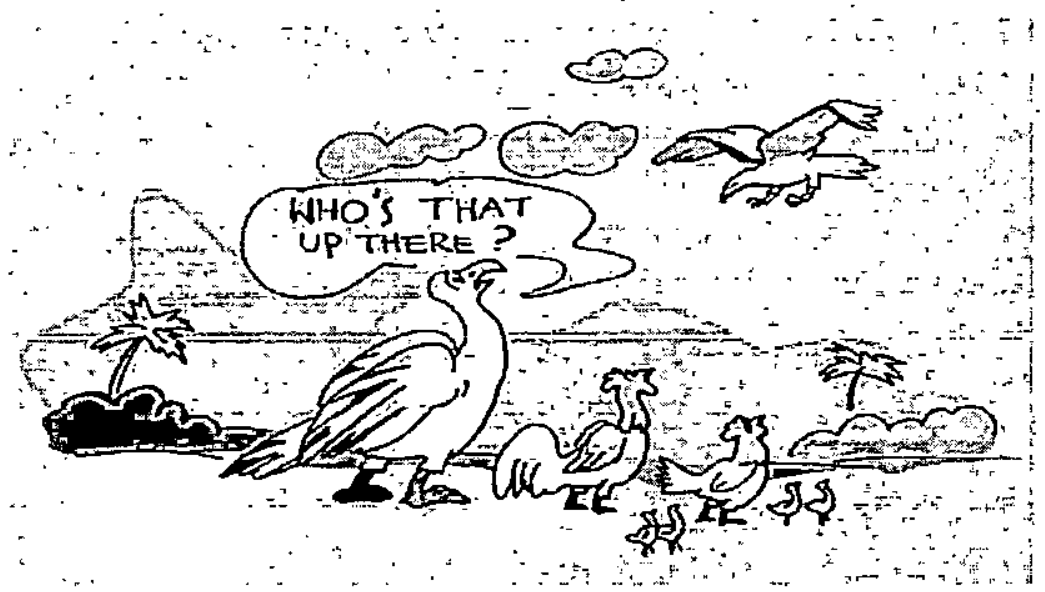

At this point the researcher pointed out that the big bird on the ground was an eagle. Then the researcher asked some questions and discussed it with the whole class. The purpose here was to further stimulate students' interest in the topic and to introduce some of the vocabulary they may need in the later part of the section. The questions were as follows:

1. Where do eagles live?

2. Where do chickens live?

3. In the picture, what is the old eagle on the ground doing with the chickens?

4. Why does she ask, "Who's that up there?"

5. Doesn't she know that the eagle in the sky is one of her kind?

6. What are some differences between an eagle and a chicken?

7. Would you rather be an eagle or a chicken? Why?

Then the researcher came to the lesson, introducing the topics, words that can be used in giving opinion, such as:

More formal: It is my view that ...

Ibelieve that ....

Neutral: .. Ithink...

What Ithink is ....

It seems to me that ......

Ihave to say that ::...

"Tome,.... 
At the-next step, the researcher gave the students opportunity to practice the words, by putting them in sentences, giving some drills, and correcting the students' mistakes for accuracy.

Next, she gave the students a text and asked them to read the text silently. Then students were asked to sit in pairs and read the story again each other and discussed the difficult words for about 5 minutes. Then the students were asked to sit in group of four and discuss the moral value they got from the text and how can environment influence someone's life and how should they behave in their environment. As a base the researcher gave several questions. In giving their response to the questions the students should use language expressions that had been mentioned before. The questions were:

- Do you think you can be anybody you want to be?

- How do you know who you are? Do you need other people to tell you who you really are?

- Do you ever dream you are somebody else? Who?

- Do you think you are like the old eagle or the one on the air? Explain your answer.

- Which is more influential in one's life: nature or nurture?

While the students were involved in the discussion with their pairs, the researcher monitored the discussion and checked whether the students had any problems in understanding the materials. However the researcher let the students expressed their opinion went through their imagination without direct corrections and intervention. When the students had finished_the discussion, the researcher invited a representative of each group to present the result of their discussions with the rest of the class. At the end of the class, the researcher gave comments and feedback.

\section{Research Findings and Discussions}

To know the base score of the students' speaking skill the researcher together with the collaborator conducted the test. The students' performance then observed and evaluated based on the scoring rubric with speaking indicators on it: pronunciation, structure, vocabulary, fluency, and content. The result of the test showed that the average score of the students' speaking test was only 48.44 . In 
other words, the level of the students speaking skill was not yet satisfactory. The students still had difficulties in expressing their ideas, opinions, or explaining and describing something. Next the researcher and collaborator arranged the lesson by applying communicative activities in small group discussions for cycle 1 . The implementation of action in the first cycle was done in four meetings.

At the end of cycle 1 , the researcher analyzed the field notes, and the . observation checklist, the researcher found that some students got trouble in expressing their feeling, ideas, and opinions. Their problems were still in all components of speaking. :

The major mistakes made by the stiudents were in terms of structure. Basically, the mistakes occurred because the students translate Indonesian into English word by word. Whenever the students translated Indonesian into English word by word, of course, they would not use correct expression of grammar. In other words, they would use unsuitable pattern of grammar.

In term of vocabulary, many students had difficulties in choosing accurate words in expressing their ideas. Next point is about the students' skill in term of fluency and content. In term of fluency; the students had problems in speaking smoothly. They also had problems with their speech rate, and sometimes the students forced into silence because of limited language use. About the content, most of the students' mistakes were caused by unwell organized of idea of the. Moreover, most parts of their speech were not "tied" together.

The field notes and the observation sheets also reported that the students' grammar was influenced by the grammar of their mother tongue. Their vocabulary was limited, and their fluency still needed improvement. Anyway, the teaching and learning process on cycle 1 was better enough if it compared with the class before doing the research. Some of them began to motivate to speak in English. They began to enjoy the discussions. Some students began to actively sharing and building ideas, giving opinion, although some students still used their mother tongue, but they tried to open dictionary.

The field notes also reported that the class was noisy during the discussions. But the noisy class didn't mean the students hated the lesson. The noisy happened because they didn't realize their roles in the discussions, while some other students were aggressive and wanted to dominate the class. However, the noisy didn't disturb the activities. 
At the end of cycle 2, a lot of students began to have good motivation toward speaking. They began to enjoy the discussions and didn't afraid of making mistakes. Some students began to actively sharing and building ideas, giving opinion confidently. Moreover, the students began to realize their roles in the discussions. Mutual understanding among the students also improved as well.

In short, the finding indicated that teaching speaking through communicative activities in small group discussions at the third semester class A of the English Department of FKIP UNRI improved the students' speaking skill. The improvement for the three cycles can be seen at the following table:

\section{The Average.Scores of the Students" Speaking Skill}

\begin{tabular}{|l|c|c|c|c|}
\hline $\begin{array}{c}\text { Speaking } \\
\text { Indicators }\end{array}$ & $\begin{array}{c}\text { Students' Base } \\
\text { Score }\end{array}$ & $\begin{array}{c}\text { At the End } \\
\text { of Cycle 1 }\end{array}$ & $\begin{array}{c}\text { At the End } \\
\text { of Cycle 2 }\end{array}$ & $\begin{array}{c}\text { At the End } \\
\text { of Cycle 3 }\end{array}$ \\
\hline Pronunciation & 48.3 & 60.6 & 63.3 & 73.9 \\
\hline Structure & 46.7 & 53.9 & 60.0 & 71.1 \\
\hline Vocabulary & 51.7 & 56.7 & 63.9 & 75.0 \\
\hline Fluency & 48.3 & 55.6 & 63.9 & 74.4 \\
\hline Content & 46.7 & 51.7 & 61.7 & 72.8 \\
\hline Average & $\mathbf{4 8 . 3}$ & $\mathbf{5 5 . 7}$ & $\mathbf{6 2 . 6}$ & $\mathbf{7 3 . 4}$ \\
\hline
\end{tabular}

At the beginning of cycle 1 the average score of the students' speaking skill was 48.3, improved to 55.7 at the end of cycle $1 ; 62.6$ at the end of cycle 2 ; and 73.4 at the end of cycle 3. After doing the reflection, the researcher and the collaborator agreed that action research in using communicative activities in small group discussions can improve the level of students' speaking skill. They also agreed that . the research was successful enough. Therefore, they decided to end the research

\section{E. Conclusions and Suggestions}

After conducting the classroom action research in teaching speaking by applying communicative activities in small group discussions for three cycles, it can be concluded that: (1) Communicative activities in small group discussions can improve the students' speaking skill at the third semester class $A$ of the English 
Study Program of FKIP UNRI: The improvements of the students' speaking skills. are in terms of pronunciation, structure, vocabulary, fluency, and content; (2) The factors of communicative activities in small group discussions that influence the students' speaking skill are: (a) clear objectives stated and mentioned by the lecturer; (b) problem solving activities that develop the students' independent thinking and motivation; (c) a good classroom atmosphere that allow the students reduce their anxiety; (d) natural leaming process provided by the teacher; (g) uncontrolled materials that do not focus on form but content; (f) indirect corrections from the teacher that make them feel relax and speak in unstressed conditions; and (h) interaction with partners or group members in achieving their purpose.

Based on the result of this research, it is suggested that: (1) The researcher as an English lecturer should continue using communicative activities in small group discussions in teaching speaking, (2) The researcher as an English lecturer has to continue conducting further research and applying communicative activities in small group discussions to other language skills such as listening, reading, and writing; (3) The researcher as an English lecturer should also be more creative in presenting the meaningful materials to make the students interested in studying, especially in improving their speaking skill.

\section{Bibliography}

Applebaum, Brucce, 2007. Communicative Language Teaching: Theory, Practice and Experience http://www.kopertis2.org/jurnal/ humaniora.pdf. retrieved on September 10,2008.

Brown, H. Douglas, 1994. Principles of Language Learning and Teaching. Englewood Cliffs, New Jersey. Prentice Hall Inc.

Brown, H. Douglas, 2004. “Assessing Speaking" Language Assessment: Principal and Classroom Practice. San Francisco: Pearson Education. Inc.

Brown, Gillian and George Yule, 1999. Teaching the second Language (2nd ed). Melboume. Cambridge University Press.

Burn A and Joyce, 1997. Focis on Speakin, Sydney: National Center and Research. 
. Dobson, Yulia M: 1981. Effective Techniques for English Conversation Groups. Washington, D.C. United States Information Agency.

Gay. R. L. And Airisian, 2000. Educational Research. New Jersey. Prentice Hall Haris, David P., 1969. Testing English as a Second Language. New York: Mc Grow Hill.

Harris, Grace. A. 2007. Minimizing the Perils of Small Group Discussions. (http:www.vcu.edu/cte/resources/nfg/14-04-minimizing-perils-of.htm). Retrieved on November 12,2008

Harmer, Jeremy, 1991. The Practice of English Language Teaching. New York. Longman.

Hornby, 1987. Oxford Learner Dictionary. Washington. Oxford University Press.

Kemmis, Stephen and Robert, L., 1998. The Action Research Planner (3rd ed.) Victoria: Deakin University.

Lastrawati, 2008. Improving Students' Speaking Skill Through Communicative Games at VIII.1 Grade of SMPN 4 Batisangkar: Unpublished thesis. Padang: Program Pascasarjana UNP.

Littlewood, william, 1991. Communicative Language Teaching. New York. Cambridge University Press.

Mills, Geoffrey E., 2003. Action Research: A Guide for the Teacher researcher. New-Jersey: Person Education Inc.

Nunan, David, 1992. Research Methods in Language Learning. Cambridge University Press. .

-.----, 1998. Language Teaching Methodology. Teacher Education and Development. A textbook for Teachers. Macquqrie University, Sydney.

O'Mallay, J. Michael, and Lorraine Valdez Pierce, 1996. Authentic Assessment for English Languagralearners, Addison, Wesley Publishing Company.

Prodromou, Luke, 1994. Mixed Ability Classes, London, Macmillan Publishers. Thornbury,Scott. William, 2006. How to Teach Speaking. England. Longman 
Ur, Penny, 2000. A Course in Language Teaching: Practice and Theory: = Cambridge. Cambridge University Press.

Weir, C.J., 1993. Understanding and Developing Language Test. New York. Prentic Hal

Zainil, 2006. "Actional Functional Model (AFM)" Teacher's guide for Intermediate Students. Padang, UNP Press. 